July 2017

\title{
Problem-Based Learning and the Training of Secondary Social Studies Teachers: A Case Study of Candidate Perceptions during their Field Experience
}

Charles T. Wynn Sr.

Kennesaw State University, cwynn6@kennesaw.edu

William Okie

wokie1@kennesaw.edu

Follow this and additional works at: https://digitalcommons.georgiasouthern.edu/ij-sotl

\section{Recommended Citation}

Wynn, Charles T. Sr. and Okie, William (2017) "Problem-Based Learning and the Training of Secondary Social Studies Teachers: A Case Study of Candidate Perceptions during their Field Experience," International Journal for the Scholarship of Teaching and Learning: Vol. 11: No. 2, Article 16. Available at: https://doi.org/10.20429/ijsotl.2017.110216 


\title{
Problem-Based Learning and the Training of Secondary Social Studies Teachers: A Case Study of Candidate Perceptions during their Field Experience
}

\begin{abstract}
We present results of a case study in which we analyzed the impact of problem-based learning (PBL) and cognitive scaffolding techniques introduced in our secondary social studies methods course on the perceptions and practices of 12 preservice teachers (PSTs) during their fall practicum and spring student teaching. Our PSTs reported teaching 54 PBL lessons and identified factors that encouraged their use of PBL: methods course PBL experiences; improved student exam scores and writing skills, increased engagement; and improved collaborative, deliberative, and cognitive skills. Discouraging factors included the time and effort to plan PBL lessons, coverage demands, and standardized testing. Findings suggest that PBL methodology, supported by professorial modeling and metacognitive training, had a transformative impact on our PSTs in terms of how they perceived their relationship with their students, the student outcomes they sought to facilitate, and their operational understanding the goals of social studies education offered by the National Council for the Social Studies.
\end{abstract}

\section{Keywords}

problem-based learning, social studies education, postformal thinking, teacher education

\section{Creative Commons License}

c) (i) $(\Theta$

This work is licensed under a Creative Commons Attribution-Noncommercial-No Derivative Works 4.0 License.

\section{Cover Page Footnote}

Our study was supported by a grant from the Center for Excellence in Teaching and Learning at Kennesaw State University. 


\title{
Problem-Based Learning and the Training of Secondary Social Studies Teachers: A Case Study of Candidate Perceptions during their Field Experience
}

\author{
Charles T. Wynn, Sr. and William Thomas Okie \\ Department of History and Philosophy, Kennesaw State University, Kennesaw, GA 30144, USA
}

(Received 29 September 2016; Accepted I March 2017)

\begin{abstract}
We present results of a case study in which we analyzed the impact of problem-based learning (PBL) and cognitive scaffolding techniques introduced in our secondary social studies methods course on the perceptions and practices of 12 preservice teachers (PSTs) during their fall practicum and spring student teaching. Our PSTs reported teaching 54 PBL lessons and identified factors that encouraged their use of PBL: methods course PBL experiences; improved student exam scores and writing skills, increased engagement; and improved collaborative, deliberative, and cognitive skills. Discouraging factors included the time and effort to plan PBL lessons, coverage demands, and standardized testing. Findings suggest that PBL methodology, supported by professorial modeling and metacognitive training, had a transformative impact on our PSTs in terms of how they perceived their relationship with their students, the student outcomes they sought to facilitate, and their operational understanding the goals of social studies education offered by the National Council for the Social Studies.
\end{abstract}

\section{INTRODUCTION AND RESEARCH RATIONALE}

The primary purpose of social studies, according to the National Council for the Social Studies (2010), is to help young people become reasoned citizen decision-makers through the development and application of knowledge, inquiry processes, data collection and analysis, collaboration, decision-making, and problem-solving. From Shirley Engle's (1960) thesis "that quality decision making should be the central concern of social studies instruction," (p. 306) to Carol Hahn's (1994) call for student engagement "in the processes by which public issues are resolved in a democracy" (p. 204), social studies educators have long advocated the use of teaching methods that prompt students to practice and acquire these decisionmaking/problem-solving skill-sets with the guidance of skilled social studies teachers. Parker, Mueller, \& Wendling (1989) posited that problem/issue-based instruction is best in preparing citizens to make decisions collectively for the public good.

Despite the presence of social studies in the secondary curriculum for more than a century in the U.S., however, our collective capacity to address effectively the pressing issues of the day is questionable at best. Shawn Rosenberg (2004) argued that most citizens lack the reasoning ability to participate effectively in a deliberative democracy and develop consensus-based solutions to problems and issues. Similarly, Jan Inglis and Margaret Steele (2005) pointed to a wide gap between the current problems we face and the reasoning ability, emotional maturity, and inter-societal deliberative capacity we need to effectively address these problems. Michael Basseches (2005) noted that when faced with complex problems and issues, individuals often make decisions based on inadequate intuitive or emotional thinking, loosely defined as, "if it feels right-it is right." The prevalence of intuitive and emotional thinking in problem-solving and decision-making, coupled with an inability to think through problems from multiple perspectives, in an alarming number of both high school and college-educated citizens, is troubling considering the primary goal of social studies is to facilitate reasoned citizen decision-makers.
As teacher educators, we find this cognitive gap sobering, to say the least. What can we do about it as social studies educators? Rosenberg (2004), Basseches (2005), and Inglis and Steele (2005) suggested pedagogical devices that guide citizens to gain the cognitive skills required for effective deliberative and democratic participation in addressing pressing problems and issues. These pedagogies must explicitly confront individuals with the diverse perspectives, multiple truths, and contradictions inherent in complex problems and issues in order to guide them to practice and gain these advanced cognitive skills (Basseches, 2005).

If social studies can be part of a solution in filling this cognitive gap, it will be through a secondary social studies curriculum rich in problem-solving/decision-making opportunities. Such a curriculum could provide students with guidance and scaffolding that helps them practice and gain the advanced cognitive skills necessary to become effective citizen decision-makers. And such a curriculum must be implemented by teachers who have been trained to lead students in problem-based learning. Is it possible, we wondered, that a problem-based secondary social studies methods course could make inroads?

Prompted by all of the above, we changed our secondary social studies methods course at a large southeastern university to include a more explicit focus on guiding our preservice teachers (PSTs) to gain experience with, and practice in, problem-based learning (PBL) and the related cognitive dynamics. We conducted the current study to analyze the impact of the PBL-based revisions to our methods course as perceived by our PSTs. We selected PBL due to the alignment between the empirical evidence of outcomes facilitated by the method and the emphasis the National Council for the Social Studies (2010) places on the decision-making and problem-solving skill-sets required to be effective, competent citizens. We posited that immersing our students in multiple PBL experiences and guiding them to discover this alignment and to recognize the advanced thinking systems we guided them to practice during PBL activities in our methods course would facilitate our PSTs' use of PBL when they taught in the field. In summary, we developed this study to identify factors they perceived as 
affecting their use of PBL, and to provide us with systematic feedback on how our PBL-based course revisions influenced our PSTs in the field.

\section{Problem-Based Learning and the Development of Advanced Cognitive Skills} The PBL method is generally defined as focused, experiential learning organized around the investigation of and resolution of messy, complex, authentic problems (Torp and Sage, 2002, Hmelo-Silver, 2004), through which students use advanced thinking processes (Lenkauskaite \& Mazeikiene, 2012). PBL confronts students with authentic problems as a catalyst for them to practice and gain higher order thinking skills, self-direction, and the ability to reflect on their own learning (Borrows, 1986; Hmelo-Silver, 2004; Norman \& Schmidt, 1992).

PBL has been found to increase content knowledge retention and improve student ability to transfer problemsolving processes into new and more complex circumstances (Blumberg, 2000; Cognition and Technology Group at Vanderbilt [CTVG], 1997; Maxwell, Bellisimo, and Mergendoller, 200 I; Mergendoller, Maxwell, and Bellisimo, 2006). A meta-analysis by Strobel and van Bareveld (2009) indicated that PBL was significantly more effective than traditional instruction in training competent and skilled practitioners and in promoting long-term retention of knowledge and skills. Hung (20I3) highlighted the practical dynamic of PBL as an instructional method that prepares students for real-world problem-solving contexts.

Wynn, Mosholder, and Larsen $(2014,2016)$ found that PBL, with an explicit metacognitive reflection component, was more effective than traditional instruction in promoting postformal thinking, specifically relativistic and dialectical thinking, in a survey history course context. They recommended $\mathrm{PBL}$ as an ideal instructional method to confront students with the contradictions and complexities inherent in real-world problems and issues in order to guide them to practice and gain postformal thinking skills, skillsets that support the more effective deliberative and democratic participation referenced by Rosenberg, and Inglis and Steele. Wynn and Mosholder (2016) summarized the relativistic and dialectical thinking dynamics involved in postformal problem solving:

Relativistic Thinkers-

- $\quad$ expand the lens of problem-solving beyond fixed truths or good versus bad;

- realize that context, complexities, and contradictions are key to understanding a problem/issue and central to developing possible resolution alternatives;

- recognize that some problems/issues may not have workable solutions.

Dialectical Thinkers-

- combine relativistic thinking with the recognition that contradictions within a problem or issue are interrelated and connected;

- use inconsistencies and contradictions as catalysts for problem-solving;

- $\quad$ seek to determine why opposing sides believe what they believe;
- $\quad$ use this knowledge to develop resolution alternatives;

- recognize that on-going changes will challenge any stability or solution reached and will often produce a tension-to-resolution-to-tension cycle dynamic.

\section{PBL in Teacher Training}

Saye et al., (2009) posited that teachers rarely utilize problem/issue-based instruction due to lack of models that allow them to envision the related successful student outcomes, and further attributed its rarity to teachers' reliance on "craft teaching knowledge" (p. 7) - that is, knowledge generated by practitioners in the authentic context of classrooms - and their tendency to discount theory-based knowledge and related instructional practices. Saye et al., (2009) also attributed teacher resistance to using PBL practices to "teacher dispositions; beliefs about knowledge, teaching, and learning, and pragmatic concerns such as class sizes, isolation from peers, and the time, energy, and cognitive demands required by such practice (Onosko, 1991; Rossi, 1995; Saye, 1998; Schlechty, 1993; Windschitl, 2002)" (p. 7). Saye and Brush (1999, 2000, 200 I, 2002, 2004, 2007, 2009) have studied how to support teachers in the implementation of PBL in secondary social studies classrooms and found that modeling, scaffolding, and collaboration were effective in assisting teachers to utilize PBL and to link a holistic theory-based framework to the practice of problem-based historical inquiry. Brush and Saye (2014) found that their integration of a PBL instructional model (problem-based historical inquiry $\mathrm{PBHI}$ throughout a secondary social studies teacher education program was effective in facilitating the recognition and incorporation of core components of $\mathrm{PBHI}$ by preservice teachers in their courses and field experiences, and additionally, enhanced their ability to articulate their reasoning for their instructional decisions. The results of their studies also suggested that PBL supports should be grounded in learning experiences before they become "fully assessable or legitimate" (Saye, et al., 2009, p. 33).

\section{Research Questions}

Our primary research question was based on the work referenced above and addressed the extent to which our PBL modeling and scaffolding practices in a secondary social studies methods course context influenced our PSTs' perceptions of their use of PBL in the field. Specifically, we addressed the extent to which our PSTs' confidence and proficiency in planning and implementing PBL lessons would be strengthened by immersing them in multiple PBL experiences, guiding them to recognize and practice the postformal cognitive skills inherent in effective decisionmaking, and encouraging them to apply the related theoretical frameworks. We also addressed the extent to which the teaching context in which our PSTs were placed would affect the extent to which they utilized PBL. Therefore, our primary research question was as follows: What factors will affect the use and perceptions of PBL among our social studies PSTs during their fall practicum and spring student teaching experience?

Several related sub-questions also guided our study: 
I. How will our PSTs perceive their level of preparation and level of confidence in implementing PBL during their fall practicum and spring student teaching?

2. To what extent will our PSTs utilize PBL during their fall practicum and spring student teaching and what positive and negative factors will they perceive related to their use of PBL?

3. What factors will our PSTs perceive as encouraging or discouraging their use of PBL during their fall practicum and spring student teaching?

\section{RESEARCH DESIGN}

We chose a case study approach in order to gain an understanding of our PSTs' perceptions related to the above questions in the professional contexts of their fall methods course/practicum setting and their spring student teaching setting. This approach allowed us to take into consideration the lived realities and nuances experienced by our PSTs in a way that would not be possible through a quantitative approach (Glesne, 2006). Through a case study approach, specifically through data source triangulation, we identified themes and consistencies that helped explain factors that affected our PSTs' use and perception of PBL over time and in different secondary social studies classrooms (Stake, 1995; Yin, 2014).

\section{Participants and Instructional Settings}

Sixteen students enrolled in the required senior secondary social studies methods block at our university in the fall of 2015. This methods block included the social studies methods course, which met one day a week for two hours and 45 minutes for 16 weeks and a middle school (6-8) practicum in which students completed at least 75 hours of teaching under the supervision of their assigned classroom teacher (CT) and their university supervisor. Three of the participants were in a pilot program during the spring of 2015 in which they completed a middle school field experience, and therefore, were placed in a high school to complete their fall practicum. Each of the sixteen students agreed to participate in the study in which they completed an end-of-practicum questionnaire, an end-of- practicum focus group, an end-of-student-teaching questionnaire, and an end-of-student-teaching focus group.

The purpose of the questionnaires and focus groups was to determine our PSTs' perceptions of the following: I) preparation and confidence to plan and teach PBL lessons; 2) the number of PBL lessons they taught; 3 ) the positive aspects/outcomes and challenges of the PBL lesson(s) they taught, 4) factors that encouraged and discouraged the use of PBL; and 5) the extent to which they planned on using $\mathrm{PBL}$ during student teaching and during their first teaching job.

Of the 16 original participants, 13 completed the methods course/practicum and thus completed the end-ofpracticum questionnaire and focus group session. Participants who successfully completed the fall practicum were placed in a high school social studies classroom for student teaching during spring semester 2016, which lasted 16 weeks. Twelve of the 13 participants completed student teaching and completed the end- of-student-teaching questionnaire and the second focus group session. Therefore, data analyzed in the current study were limited to these I 2 PSTs. Table I (Appendix E) shows each PST's pseudonym and the fall 2015 and spring 2016 field placements and subject(s) taught.

Table I also shows the age at the time of the study, gender, and race/ethnicity of each of the 12 PSTs. Eleven were between the age of 22 and 25 . While pursuing their degrees, most of our PSTs had part-time jobs, which extended the time needed to complete the History Education Program requirements. Lou (age 27) returned to school to complete his degree in history education. Five of the participants were female and seven were male. One of the participants was African American and one was Hispanic. Each of the PSTs were from the same state as our university.

Table 2 (Appendix E) includes the weekly topical outline from our methods course syllabus. The primary focus of the first three weeks of the course was to immerse students in a learner-centered/problem-based learning dynamic through which we could model PBL and PSTs could experience the method and the related learning and cognitive outcomes. The PBL procedures used in our study were based on Wynn's PBL instructional model (Wynn, 2010, 2015; Wynn et al., 2014, 2016) which includes a metacognitive reflective component.

Step I- Introduction of the Problem:

The primary focus in Step I is to pique student interest (create a need to know more), establish "stakeholdership," and explicitly portray the problem/issue as multidimensional with multiple truths.

Step 2- Initiation of PBL Events: Argumentation and Student Inquiry: Step 2 includes a decisionbased/argumentation structure in which students generate arguments, and work to recognize conflicts and contradictions among competing positions.

Step 3- Problem Solution: Students generate solutions/decisions, deliberate to select the most appropriate one, compare it to the actual historical decision(s) or outcome(s), and then evaluate its consequences.

Step 3 ends with a guided reflection on the types of thinking strategies utilized by students, and the successes or failures of each through the use of a metacognitive reflection questionnaire.

(Adapted from Wynn, et al., 2016, p. 4-5)

After the initial PBL activity, we prompted our PSTs to analyze and compare their PBL learning experience to the goals and purpose of social studies education as stated in the National Curriculum Standards of Social Studies (NCSS, 20I0) and the related learning expectations found in chapter one: "Learners build knowledge as they work to integrate new information into existing cognitive constructs, and engage in processes that develop their abilities to think, reason, conduct research and attain understanding as they encounter new concepts, principles, and issues." (p. 10). We used this comparison to prompt 
our PSTs to identify the cognitive constructs they learned to recognize and practice during the initial PBL activity, specifically, postformal thinking systems (relativistic and dialectical) and those that may not have been adequate (concrete, formal/closed systems/absolutist thinking, intuitive/emotional thinking). After the first PBL activity, we continued to guide our PSTs to identify the cognitive skills involved in each of the methods they experienced and practiced as the course progressed, including concept development, cooperative learning, lecture/discussion, etc., and two additional PBL activities.

\section{DATA COLLECTION AND ANALYSIS}

We collected data at two points during the 2015-2016 academic year. The field director of our History Education Program (HIED) administered the End of Practicum Questionnaire in December 20 I5. The HIED Field Director coordinated field placements and supervision assignments for the methods course practicum and was not involved in the assessment of assignments completed by participants. The instructors of record were the researchers. All questionnaires included a three-digit code to maintain the anonymity of each participant. The End of Practicum Focus Group session (Appendix B) was audio recorded after participants completed the questionnaire and was facilitated by our field director. The facilitator read each question on the questionnaire to prompt our PSTs to expand on, explain, add to, or discuss their responses on the questionnaire. The focus session was limited to 45 minutes. Participants completed the End of Student Teaching Questionnaire (Appendix C) and the End of Student Teaching Focus Group session (Appendix D) during the final week of student teaching in April 2016. Data were collected using the same procedures followed during the December data collection/focus group session. We defined problem/decision-based learning on both questionnaires as "experiential learning (minds-on, hands-on) organized around the investigation of and resolution of messy, real world problems."

We used open coding to analyze and triangulate the data in order to identify themes among individual participants and among the 12 PSTs as a group related to the research questions. Responses to each prompt on the end-of-practicum and end-of-student-teaching questionnaires and during both focus group sessions were coded by the emergence of themes relevant to the primary research question and related sub-questions. We constructed case reports on each PST to identify common patterns and contradictions in responses to questionnaire and focus group prompts. Each individual report was then crosschecked with other PST reports to identify prominent and consistent themes. These themes were then used to provide a description of the experiences of each PST relevant to those themes and to other PSTs' experiences. Our analysis of these reports provided the empirical data from which we drew conclusions regarding the following: I) perceptions of PSTs' level of preparation and level of confidence in implementing problem/decision-based activities, 2) the extent to which they utilized PBL and their perceptions of positive and negative factors related to the methods implementation, and 3) factors they identified as encouraging or discouraging their use of PBL.

\section{RESULTS \\ End of Practicum}

Two primary themes emerged from the cross-case analysis of the post-practicum responses regarding our PSTs' perceptions of their readiness to teach PBL lessons. First, they were tentatively confident about planning and implementing PBL and attributed that confidence to their experience with multiple PBL activities in the methods course itself. Our PSTs ranked their level of preparation and confidence ( 0 to 3 ) in planning and teaching a PBL lesson as somewhat to very prepared/confident (Prepared-M = 2.33, Confident-M $=2.5$ ). In a representative comment, lan explained that he knows "what PBL lessons are and how to implement them in the classroom. My score of 2 rather than 3 is based on lack of practice." Jane found that some lessons were more amenable to PBL than others were. "I feel like it $(\mathrm{PBL})$ requires a certain level of creativity that I am still trying to master, although this class (methods) has made it clear how to distinguish and approach PBL." Carly explained her tentativeness in terms of planning for the unexpected: "I also have to prep for any tough questions that students may have in regards to their decision-making," she said.

Second, as Carly's comments suggest, our PSTs were very anxious about how their students would respond to PBL lessons, which may be reflective of their recognition that PBL rarely or never occurred in their practicum classrooms. They generally framed their anxiety in terms of "unexpected issues" that may arise during the activities and the extent to which they had the knowledge and skill to address effectively those issues or questions. Ten of the II PSTs who taught a PBL lesson indicated their level of anxiety diminished and their confidence rose after their first PBL teaching experience, and that gaining more practice in implementing PBL lessons would increase their effectiveness and confidence. The one exception was Bob, who implemented one PBL activity that did "not go very well" and thus damaged his confidence. He described the challenge of planning and teaching a PBL lesson as "intimidating for a novice teacher." In spite of the anxiety, II of 12 PSTs reported that they developed and taught at least one PBL lesson during their practicum. The total number of PBL lessons reported by the group was 22 , with Bob and Hank teaching one; Carly, Ed, Frank, Gary, lan, Jane, Kathy, and Lou each teaching two; and Debra teaching four. Anne did not teach a PBL lesson. She reported that her cooperating teacher (6 $6^{\text {th }}$ grade World Area Studies) would not allow her to implement a PBL activity. "My CT did not believe the students were at a level they would have needed to be to implement a problem-based activity successfully."

Our PSTs' perceptions of positive factors related to their decision to use PBL included improved student performance on exams, improved writing skills, significantly higher levels of engagement, fewer classroom management issues or disruptive students, and improved deliberative and cognitive skills. lan reported that with "content covered by PBL, they get it! Their test scores are better! They can write about their experiences. It was amazing watching 
concrete thinkers gain the cognitive skills necessary to effectively solve the problem." Lou concurred: "PBL allows you to take standards to the next level. Their essay writing improves. They get it! My students had never been in a PBL environment before. It was cool to see kids who normally were not engaged become interested and involved." Kathy observed a marked change in student discussion skills: "Students are ready to voice their opinions. ... It's neat to see them listen to each other's opinions and open up their minds to consider them."

As these comments indicate, our PSTs perceived PBL lessons as potentially transformative, in terms of both the learning environment and the relationship between students and teacher. This transformative potential was starkest in the case of Frank, who described PBL as a "game changer":

Personal relationships changed. They saw me in a different light after PBL. PBL laid the foundation for their thinking differently and their thinking about me differently. It opened up conversations that hadn't happened before. Before, I thought I was trapped in a box fitting this certain thing that is a teacher. With PBL, I have this knowledge and the ability to do things better than I'm told they have to be done.

Other PSTs agreed. "Students were able to take a social studies problem," Gary explained, "and get directly involved with the content through their own decisionmaking and observations rather than rote memorization." Jane claimed that she "became a facilitator in the learning process." Bob, despite the fact that his PBL lesson went poorly, acknowledged "students cared about the activity overall and liked to consider competing perspectives."

According to our PSTs, the transformative power of PBL was particularly evident in students who normally struggled with social studies content, who "checked out" or were disruptive during traditional instruction. "Students who would have been problems became my best students," said lan, who continued, "PBL gave them an outlet to be exemplary students." Jane observed "the level of interaction and how they worked with each other really improved." According to Carly, in a comment that clearly resonated with all PSTs during the focus group session, PBL techniques made classroom management easier. "It takes a lot of planning to get there," she said, "but once there you can lay back and let the students take the reins. It helps with classroom management and motivation. Our job becomes easier."

In addition, the PBL experiences in our methods course and the alignment they saw between PBL outcomes and the goals of social studies education encouraged our PSTs to use PBL in their practicum classrooms. "My experience in [the methods] class encouraged me to do this," said Kathy. "I saw, through PBL lessons, how engaging and interactive PBL lessons can be. Also, PBL lessons align so well with the purpose of social studies, promoting civic competence." Finally, PSTs pointed to the transformative impact PBL lessons can have on students as an encouraging factor. Again, Frank offered a powerful example:
One student in particular was a student who has an internal seizure disorder, which makes her lose up to five minutes of time at a time. Her scores struggled until PBL. In our debate, she shined. From then on, she was excited about class and it made all of the difference in her performance. On our Civil War test, she scored a perfect score. With just one problembased activity, she totally changed her perspective on history. Each time I plan a PBL, I will think about how the activity changed her whole attitude toward school.

Our PSTs were in full agreement on the most discouraging or limiting factors regarding $\mathrm{PBL}$ implementation during their practicum: time to implement, time to plan, coverage demands, standardized testing, and lack of student experience with PBL. "It took me 24 hours to plan a PBL lesson that lasted an hour and a half," Kathy acknowledged. "The effort it took limited my ability to do more." lan agreed: "It is highly improbable to be able to teach only these quality lessons and cover all the content required by the end of the year." Carly also pointed to standardized testing as a discouraging factor: "Decisionmaking sadly falls to the back burner," she said. "If students were to be tested on their ability to make and defend arguments, this (PBL) would be implemented in the classroom way more because there would be a real emphasis on its importance." According to Frank, lack of familiarity exacerbated this coverage/time conundrum. "Students are not overly familiar with PBL," he said, "so it takes a little more planning time to get the desired results." Despite these discouraging factors, each of our 12 PSTs planned on using multiple PBL lessons during student teaching in the spring of 2016 due to the following factors: I) the outcomes facilitated by PBL lessons (content/concept understanding, cognitive and deliberative skill development, writing skill development, level of engagement, excitement, fun, etc.), and 2) their increased level of readiness to plan and implement PBL lessons after their practicum experience.

\section{End of Student Teaching}

We were encouraged, but not altogether surprised, to find enthusiasm for PBL during the fall practicum, when our PSTs were meeting with us every week and experiencing PBL activities and the related theoretical frameworks. We wondered, though, whether the experience in student teaching would be markedly different, with our PSTs simply discouraged and overwhelmed with the constraints of their particular classroom and looming end-of-course-testing. We did find more frustration with high-stakes testing in responses to the spring questionnaire and focus group, but our PSTs remained remarkably consistent in their optimism about PBL.

The themes that emerged from the cross-case analysis of the post-student-teaching responses regarding their perceptions of readiness to teach PBL lessons were similar to those identified from the practicum data. A comparison of PSTs' experiences with PBL during their practicum and student teaching yielded an increase in their 
overall ranking of their level of preparedness in planning and teaching PBL (Student Teaching $M=2.58$ v. Practicum M $=2.33$ ) with seven of our I2 PST selecting 3-Very Prepared. Their level of confidence to plan and teach PBL lessons remained unchanged during student teaching (STM and PM $=2.5$ ). Anne scored her level of confidence a two due to the fact that she didn't teach a PBL lesson during her practicum. As we noted above, Bob considered his single experience with implementing PBL during the practicum as "not going well," which supported his student teaching score of I-Not Confident). The experiences of Anne and Bob notwithstanding, overall the group felt quite confident with PBL in spring 2016. As Ed put it:

I felt very prepared to teach problem/decisionbased activities during my student teaching experience. I think that is a credit to our professors from last semester who drilled us on the importance of students being involved in their learning and how these lessons can help them get to higher levels of thinking. It also helps having done PBLs last semester so I had a better feel for what I was doing.

Eleven of 12 PSTs reported developing and teaching at least one or more PBL lesson during student teaching. The total number of PBL lessons reported by the group was 32, with Frank and Hank teaching one; Ed, Gary and Lou teaching two; Anne and Carly teaching three; Debra and Kathy teaching four, and lan and Jane teaching five. Bob did not teach a PBL lesson during his student teaching experience. He explained that his negative experience during his practicum and his concerns over classroom management were key factors in his decision.

The PSTs identified the following encouraging factors associated with PBL, which were similar to those they identified after their practicum experience: improved student performance on exams, improved writing skills, significantly higher levels of engagement, fewer classroom management issues or disruptive students, and improved deliberative and cognitive skills. Again, their comments focused on the transformative impact of PBL, although after student teaching they were a bit more specific in their explanations regarding the context, process, and products of problem-solving/decision-making. For example, Debra's students "had to develop a plan for dealing with immigration" in the late nineteenth and early twentieth centuries. "My inclusion students developed higher level of thinking which could be seen in their plan of action," she said. "One student even made the connection with immigration today." Jane's class addressed the current immigration crisis in Europe. "I loved seeing the authentic solutions that students came up with based on information they were given. At the end of the day, the solutions might be different, but they all had the goal in mind to promote human rights." Our PSTs also reiterated the benefits of class deliberation during PBL lessons. "A lot of people think social studies is simple," Jane said. "My students know it's not. They came up with their own solutions. They understand there isn't one truth. There are multiple truths. Their solutions were complex. Coming to one solution as a class was one of the most powerful results of PBL, watching these students come together and deliberate to solve problems."

As in the fall, our PSTs remarked on the visible increase in engagement and motivation for their students during student teaching. According to Debra and Anne, students were so motivated that they neglected their other work: "I had a student get in trouble for doing my work in another teacher's classroom," said Debra. "He told the teacher he had to be prepared for my class. We had a debate and the work had to be done. I got reprimanded, but I was really jumping up and down. That was so positive for me!" Anne had a "similar experience," with other teachers telling her "students were preparing for my PBLs in their class."

The negative/discouraging factors associated with PBL during student teaching were similar to those identified at the end of their practicum: time, coverage, and CT pacing. If anything, these factors loomed larger in student teaching than they had in the practicum. Carly's explanation, with its clipped sentences and exclamations, mimicked the experience of trying to use PBLs in the spring:

\begin{abstract}
We have the EOCTs (End of Course Tests) next week. We are on Standard 22. We have to cover the Civil Rights Movement and everything from Watergate to 2001 in four days. The kids want to debate and do PBLs on topics that are most relevant to them and would be so helpful, but we have to cram this stuff down their throats and it makes me mad. We're losing three weeks on stupid standardized testing. This is the stuff they need to be participatory citizens! It really stinks not to have the time to do awesome problem-based activities with this stuff because this is actually extremely relevant to their lives today and the world around them.
\end{abstract}

Each of our PSTs concurred with Carly's observation during the focus group session and shared similar comments. Our PSTs again noted the additional planning time associated with PBL lessons as a limiting factor, and Debra and Bob noted that differentiating PBL lessons for students with special needs or specific learning preferences was often challenging.

Despite these challenges, each of our 12 PSTs stated they planned to use multiple PBL lessons once employed as secondary history/social studies teachers, pointing to the following as primary reasons: higher levels of engagement, students practicing advanced cognitive skills and meaningfully applying content, and student outcomes that align with goals of social studies education. Even the PSTs with the least experience professed their intent to use PBL. "I plan to implement PBLs as I further my teaching career," Anne declared. "These activities are not only fun and engaging, but when planned and implemented properly, they enable students to think critically about content." Bob, who implemented no PBL activities during student teaching, was similarly emphatic. "Yes. I do plan to use PBLs in my teaching career," he said, "because I believe they encompass the primary purpose of social studies which is encouraging the development of students' abilities related to being 
informed citizen decision-makers. They are also engaging, student-centered activities that can help students to learn the content in an authentic manner." Frank looked forward to escaping the limitations he felt during student teaching. "I will have the opportunity to set the trajectory and rhythm of my class from the onset," he said. "I took this semester as an opportunity to try a shotgun blast of different ideas. I got to see what worked and what didn't. PBL works!"

\section{DISCUSSION}

We developed this study to analyze the impact the PBLbased changes to our methods course had on our PSTs use and perceptions of PBL during their fall practicum and spring student teaching. We posited that an immersion of our PSTs in multiple PBL experiences and the related cognitive dynamics in our methods course and our explicit focus on the alignment between PBL outcomes and the goals of social studies and the related learning dynamics as defined by NCSS, would facilitate our students' use of PBL when they taught in the field and increase their confidence and proficiency in planning and implementing PBL lessons. After examining the results, we are encouraged by the potential role of a PBL-oriented methods course in guiding secondary social studies PSTs to be effective classroom teachers.

The sheer number of PBL lessons our PSTs reported implementing during their fall practicum and spring student teaching experience (54) was encouraging. We did not require our PSTs to develop and teach a PBL lesson in the field at any point during the fall methods block or student teaching. We hoped our PSTs would make a professional decision to utilize PBL as they saw fit based on their own experiences as learners and the extent to which they believed that PBL would be the best method to facilitate the desired student outcomes as each unit was planned. End-of-practicum and end-of-student-teaching comments indicated that our PSTs felt prepared and relatively confident to plan and teach PBL lessons and attributed their readiness to the experiences they gained as learners in our methods course and as teachers in the field.

Reports of PBL as a transformative pedagogy among our PSTs was also encouraging. Eleven of our 12 PSTs shared comments that explicitly identified the potential power of PBL to improve the learning environment in contrast to the traditional learning environment that was common in their classrooms. They perceived the facilitative, collaborative, and deliberative dynamics of PBL to be positive and perpetuating factors in the use of PBL. Perhaps Frank best framed this transformative dynamic by referring to it as the "game changer," or the point at which our PSTs began defining themselves outside the parameters of traditional social studies teaching after successfully implementing PBL. They perceived that their students saw them differently as well.

We were very pleased by the extent to which our PSTs linked the successful outcomes facilitated by their PBL activities to the primary goal of social studies education. They consistently identified the more advanced cognitive skills practiced by their students during $\mathrm{PBL}$ as a positive and encouraging factor, and connected the collaborative, deliberative, and decision-making skills practiced by their students to the goal of developing effective citizen decision- makers. This was our intent as we designed our methods course. Again, it was encouraging to see our PSTs report on the extent to which they operationalized this connection in the field, and the extent to which they indicated a strong desire to continue to use PBL when they have their own social studies classrooms.

Lastly, we were encouraged by the extent to which our PSTs saw PBL as an adaptable strategy. As the year progressed and they gained more experience with PBL, they became more flexible and pragmatic in their planning and implementation of PBL lessons. Specifically, several PSTs learned to adapt their PBL lessons to fit within a limited time frame. For example, lan stated, "I learned something. You don't have to do these mega three day (PBL) lessons. On a daily basis you can do these kind of things. I learned to adapt my lessons around PBL to fit within a shorter time frame." In concurring, Jane termed these as "mini PBLs."

We were not surprised by the negative or limiting factors our PSTs identified regarding PBL. First, our PSTs perceived the planning and preparation necessary to implement an effective PBL lesson as laborious and challenging. However, they believed that the extra time and effort paid off as they witnessed and assessed student outcomes. By the end of student teaching, several PSTs discovered PBL or PBL-like activities on-line that they considered easily adaptable into the curriculum. For example, Carly stated, "There are many on-line resources I used as PBLs this semester compared to developing my own during my practicum. It's so much easier." Second, our PSTs clearly identified time limitations and the pressure to cover content in support of EOCTs as the most significant limiting factor, with Carly's comment above framing the frustration shared by the group. However, this limitation did not prevent our PSTs from implementing PBL.

\section{IMPLICATIONS AND CONCLUSIONS}

By the end of the first day of our social studies methods course on August 17, 2015, our PSTs were in the middle of a simulation of the Second Continental Congress to determine whether the American Colonies should declare independence from Britain. They lingered in the classroom beyond the designated time to continue preparing their arguments and to review primary documents. They divided preparation responsibilities and agreed to work together outside of class to complete the task. By the end of the second day of our methods course, our PSTs had made a decision on American independence and were comparing their decision to the text of the Declaration of Independence. Our PSTs had been passionately engaged in the PBL activity and the decision-making process, which was our intent. During debriefing, Frank noted that the Declaration of Independence was more meaningful after the activity. Our PSTs clearly recognized the significance of the learning dynamics they had just experienced and wanted to know more.

Our research has two important implications regarding our PBL-based changes. First, it confirms the importance of the modeling process in our secondary social studies methods course. Our PSTs identified these PBL learning experiences as a key factor in their decision to use $\mathrm{PBL}$ in the field. They wanted their students to experience 
the same kind of motivation, engagement, and learning outcomes they had experienced. Making that happen, though, required a working understanding of the postformal cognitive systems associated with advanced problem solving and decision-making as well as the procedural dynamics of $\mathrm{PBL}$ and the associated outcomes. Developing that working knowledge among preservice teachers requires both modeling and cognitive scaffolding (Saye and Brush, 1999, 2000, 200I, 2002, 2004, 2007, 2009; Wynn, 2010, Wynn, 2015; Wynn, Mosholder, and Larsen, 2014, 2016). Working knowledge in our methods course/practicum context means that we must guide PSTs to practice, distinguish between, and acquire these postformal thinking systems and demonstrate these outcomes in order to facilitate them among their students.

However, just modeling the PBL method is not enough. The second major implication of our research is that an understanding of the cognitive dynamics of PBL is also critical. Our PSTs needed guidance in metacognitive reflection in the context of PBL in order to recognize and facilitate postformal thinking skills among their students. We guided our PSTs to inductively practice and recognize the postformal thinking systems (relativistic and dialectical thinking) inherent in advanced problem solving in the context of PBL activities, and to compare their PBL experiences and learning outcomes with the goals of social studies education and the related learning expectations and the relevant theoretical frameworks. Although the results of this study cannot be generalized, they indicate that this explicit focus was perceived as effective in facilitating the use of PBL among our PSTs and in guiding them to focus on and develop more advanced cognitive skills among their students. As lan put it, "The focus on higher level thinking skills has almost become subconscious."

Our results suggest that our decision to restructure our secondary social studies methods course around PBL and the related cognitive skillsets had a transformative impact on our PSTs in terms of how they perceive their relationship with their students and the student outcomes they seek to facilitate. Their comments indicated that they are leaving their preservice training with a perspective and operational understanding of teaching and learning that aligns well with that offered by NCSS, and with the current educational reform movement that is emphasizing sustainable advanced thinking and problem-solving skills (Condliffe, 2016; AAC\&U, 20I5).

Is PBL a "game changer," as Frank said? That might depend on how we define the game. At the macro level, PBL is simply good, constructivist education in the grand progressive tradition going back more than a century. Social studies educators have for many years argued for more active and decision-based, real-world oriented curricula and methods. Yet relatively few teachers, it seems, feel either free or qualified to use PBL. However, at the micro level, at the level of individual PSTs in their classrooms, PBL can be transformative. Our PSTs attributed their participation in PBL activities and their operational understanding of related advanced thinking systems to their decision to use PBL in future teaching contexts.

Our research suggests that a dynamic, flexible PBL methodology, supported by professorial modeling and metacognitive training, can indeed change the game for our
PSTs. In that sense, the results of our study are very valuable as we continue to adapt our secondary social studies methods course and assess its effectiveness.

\section{LIMITATIONS}

We designed this study to analyze the impact of our PBLbased revisions to our social studies methods course as perceived by our PSTs in the field. To that end, data collected were based on self-reports of their experiences and their students' performance during their practicum and student teaching. Therefore, results are not generalizable to a broader context. Without observational data to triangulate the PSTs' experiences, it is difficult to draw conclusions about the quality of implementation of PBL in the classes. Collecting data from CTs and students would provide a richer, more valid, and more holistic study, as would teaching observations and a content analysis of lesson plans. We plan on working with our IRB and local school systems to expand our research accordingly.

\section{REFERENCES}

Association of American Colleges and Universities. (2015). General education maps and markers: Designing meaningful pathways to student achievement. Washington, DC: Author.

Basseches, M. (2005). The development of dialectical thinking as an approach to integration. Integral Review, I (47-63).

Blumberg, P. (2000). Evaluating the evidence that problembased learners are self-directed learners: A review of literature. In D.H. Evensen \& C.E. Hmelo (Eds.), Problem-based learning: $A$ research perspective on learning interactions (pp. 199-226). Mahwah, NJ: Lawrence Erlbaum.

Borrows, H. S. (1986). A taxonomy of problem-based learning methods. Medical Education, 20, 48I-486.

Brush, T. \& Sayes, J. (20|4). An instructional model to support problem-based historical inquiry: The persistent issues in history network. The Interdisciplinary Journal of Problem-Based Learning, 8(I), 39-50.

Condliffe, B. (2016). Project-Based Learning: A Literature Review (Working Paper). Lucas Education Foundation, Retrieved from https://s3uswest l .amazonaws.com/ler/MDRC+PBL+L iterature+Review.pdf. Accessed September 19, 2016.

Cognition and Technology Group at Vanderbilt [CTGV]. (1997). The Jasper Project: Lessons incurriculum, instruction, assessment, and professional development. Mahwah, NJ: Lawrence Erlbaum.

Engle, S. (1960). Decision making: The heart of social studies instruction. Social Education, 24(7), 301-304, 306.

Hahn, C. L. (1994). Controversial issues in history instruction. In Carretero, M. E., \& Voss, J. F. (Eds.), Cognitive and instructional processes in history and the social sciences. Hillsdale, NJ: Lawrence Erlbaum.

Hmelo-Silver, C. E. (2004). Problem-based learning: What and how students learn? Educational Psychology Review, I6(3), 235-266.

Ho, D. (2000). Dialectical thinking: Neither Eastern nor Western. American Psychologist, 55(9), 1064- 065. 
Hung, W. (2013). Problem-based learning: A learning environment for enhancing learning transfer. New Directions for Adult and Continuing Education, 137, 27 38.

Inglis, J. \& Steele, M. (2005). Complexity intelligence and cultural coaching: Navigating the gap between our societal challenges and our capacities. Integral Review, I, 36-46.

Jonassen, D. H. (20/2). Designing for decision making. Educational Technology Research \& Development, 60, 34I-359.

Lenkauskaite, J. \& Mazeikiene, N. (20I2). Challenges of introducing problem-based learning(PBL) in higher education: Selecting problems and using problems. Social Research, 2(27), 78-88.

Maxwell, N. L, Bellisimo, Y, \& Mergendoller, J. R. (200I). Problem-based learning: Modifying the medical school model for teaching high school economics. The Social Studies, 92(2), 73-78.

Mergendoller, J. R., Maxwell, N. L., \& Bellisimo, Y. (2006). The effectiveness of problem-based instruction: $A$ comparative study of instructional methods and student characteristics. International Journal of ProblemBased Learning, I (2), 49-69.

National Council for the Social Studies (2010). National curriculum standards for socials studies. Silver Spring, Maryland: NCSS.

Norman, G. R. \& Schmidt, H. G. (1992). The psychological basis for problem-based learning: A review of evidence. Academic Medicine, 67(9), 557-565.

Onosko, J. (1991). Barriers to the promotion of higher order thinking in social studies. Theory and Research in Social Education, 19(4), 34I-366.

Parker, W. D., Mueller, M. \& Wendling, L. (1989). Critical reasoning on civic issues. Theory and Research in Social Education, I 7(1), 7-32.

Rosenburg, S. (2004). Reconstructing the concept of deliberative democracy. Center for the Study of Democracy Working Papers. Retrieved from http://escholarship.org/uc/item/2rd8m486.

Rossi, J. A. (1995). In-depth study in an issue-centered social studies classroom. Theory and Research in Social Education, 23(2), 87-I20.

Saye, J. W. (1998). Technology in the classroom: The role of dispositions in teacher gatekeeping. Journal of Curriculum and Supervision, 13(3), 210-234.

Saye, J. W. \& Brush, T. (1999). Student engagement with social issues in a multimedia-supported learning environment. Theory and Research in Social Education, 27(4), 472-504.

Saye, J. W. \& Brush, T. (2000). Implementation and evaluation of a student-centered learning unit: A case study. Educational Technology Research and Development, 48(3), 79-100.

Saye, J. W. \& Brush, T. (200I). Scaffolding problem-centered teaching in traditional social studies classrooms. Paper presented at the National Council for the Social Studies Conference, Washington, D.C.

Saye, J. W. \& Brush, T. (2002). Scaffolding critical reasoning about history and social issues in multimedia- supported learning environments. Educational Technology Research and Development, 50(3), 77-96.

Saye, J. W. \& Brush, T. (2004). Scaffolding problem-centered teaching in traditional social studies classrooms. Theory and Research in Social Education, 32(3), 349-378.

Saye, J. W. \& Brush, T. (2007). Using technology-enhanced learning environments to support problem-based historical inquiry in secondary social studies classrooms. Theory and Research in Social Education, 35(2), 196-230.

Saye, J. W., Kohlmeier J., Brush, T., Mitchell, L. \& Farmer, C. (2009). Using mentoring to develop professional teaching knowledge for problem-based historical inquiry. Theory and Research in Social Education, 37(I), 6-4I.

Schlechty, P. (1993). On the frontier of school reform with trailblazers, pioneers, and settlers. Journal of Staff Development, 14(4), 46-5I.

Stake, R. E. (1995). The art of case study research. Thousand Oaks, California: SAGE.

Strobel, J., \& van Barneveld, A. (2009). When is PBL more effective? A metasynthesis of meta-analyses comparing PBL to conventional classrooms. Interdisciplinary Journal of Problem-Based Learning, 3(I), 44-58.

Torp, L., \& Sage, S. (2002). Problems and possibilities: Problembased learning for K-l6 education. $2^{\text {nd }}$ edition. Alexandria, VA: ASCD.

Windschitl, M. (2002). Framing constructivism in practice as negotiation of dilemmas: An analysis of the conceptual, pedagogical, cultural, and political challenges facing teachers. Review of Educational Research, 72(2), I3I-I75.

Wynn, C. T. (2010). Promoting cognitive growth through problem-based instruction in a first-year learning community. Journal of Learning Communities Research, 5(2), 5-I6.

Wynn, C. T., Mosholder, R. S., \& Larsen, C. A. (20I4). Measuring the effects of problem-based learning on the development of postformal thinking skills and engagement of first-year learning community students. Learning Communities Research and Practice, 2(2), Article 4.

Wynn, C. T. (20I5). A cognitive rationale for a problembased U.S. history survey. Teaching History: A Journal of Methods, 40(I), 28-42.

Wynn, C. T. \& Mosholder, R. S. (March, 2016). Facilitating Advanced Thinking Skills through Problem-Based Learning SoTL Commons Conference, Savannah, Georgia. Retrieved from http://digitalcommons.georgiasouthern.edu/sotlcomm ons/SoTL/2016/I3. Accessed September 2I, 2016.

Wynn, C. T., Mosholder, R. S., \& Larsen, C. A. (2016). Promoting postformal thinking in a U.S. history survey course: A problem-based approach. Journal of College Teaching and Learning, I3(I), I-20.

Yin, R. K. (20I4). Case study research: Design and methods. Thousand Oaks, California: SAGE. 
Code \#

\section{Appendix A}

End of Practicum Questionnaire

Problem/decision-based learning is experiential learning (minds-on, hands-on) organized around the investigation of and resolution of messy, real world problems.

This questionnaire is designed to collect information about how you perceive your level of preparation and level of confidence in using problem/decision-based activities at this point in your year-long experience and the extent to which you have utilized problem/decision-based activities so far and why or why not.

Read the item below and circle the response that best describes you.

$I=$ Not Prepared (N) 2 = Somewhat Prepared (S) 3 = Very Prepared (V)

Rank your level of preparedness to plan and teach a problem/decision-based activity during your practicum experience.

$\begin{array}{lll}N & S & V \\ \text { I } & 2 & 3\end{array}$

Briefly explain your ranking.

Read the item below and circle the response that best describes you.

$\mathrm{I}=$ Not Confident (N) 2 = Somewhat Confident (S) 3 = Very Confident (V)

Rank your level of confidence to plan and teach a problem/decision-based activity during your practicum experience.

$\begin{array}{lll}N & S & V \\ \text { I } & 2 & 3\end{array}$

Briefly explain your ranking.

How many problem/issue-based activities did you implement during your practicum experience? (Circle below)

$\begin{array}{lllllll}0 & 1 & 2 & 3 & 4 & 5 & \text { more }\end{array}$

Please list/briefly describe the activity(ies) you implemented.

What were the most positive aspects/outcomes of the problem/decision-based activity(ies) you implemented?

What were the biggest challenges you encountered as you implemented your problem/decision-based activity(ies)?

Identify and explain factors that encouraged you to use problem/decision-based activities during your practicum experience.

Identify and explain factors that discouraged or limited your use of problem/decision-based activities during your practicum experience.

Do you plan to use problem-decision/based activities during student teaching? If so, why? If not, why not? 


\section{Appendix B}

Focus Group Moderator Instructions

Read the following.

The purpose of this focus group is to allow you to expand on your questionnaire responses. I will read each question and ask you to respond. The group will have five minutes to respond to each question. I will do my best to prompt responses from each of you and facilitate group discussion as we work our way through the eight questions.

Your responses will be audio recorded per the audio recording consent form you signed in August.

**(Make sure the recorder is on and working. Have the assistant moderator take notes on participant responses. Names should not be used.)

\section{Questions}

I. Rank your level of preparedness and level of confidence to plan and teach a problem/decision-based activity during your practicum experience.

I = Not Prepared (N) 2 = Somewhat Prepared (S) 3 = Very Prepared (V)

Briefly explain your ranking.

2. How many problem/issue-based activities did you implement during your practicum experience?

Briefly describe the activity(ies) you implemented.

3. What were the most positive aspects/outcomes of the problem/decision-based activity(ies) you implemented and what were the biggest challenges you encountered as you implemented your problem/decision-based activity(ies)?

4. Identify and explain factors that encouraged you to use problem/decision-based activities during your practicum experience.

5. Identify and explain factors that discouraged or limited your use of problem/decision-based activities during your practicum experience.

6. Do you plan to use problem-decision/based activities during student teaching? If so, why? If not, why not? 
Code \#

\section{Appendix C}

\section{End of Student Teaching Questionnaire}

Problem/decision-based learning is experiential learning (minds-on, hands-on) organized around the investigation of and resolution of messy, real world problems.

This questionnaire is designed to collect information about how you perceive your level of preparation and level of confidence in using problem/decision-based activities at this point in your year-long experience and the extent to which you have utilized problem/decision-based activities so far and why or why not.

Read the item below and circle the response that best describes you.

$\mathrm{I}=$ Not Prepared (N) 2 = Somewhat Prepared (S) 3 = Very Prepared (V)

Rank your level of preparedness to plan and teach a problem/decision-based activity during your student teaching experience.

$\begin{array}{lll}N & S & V \\ I & 2 & 3\end{array}$

Briefly explain your ranking.

Read the item below and circle the response that best describes you.

$\mathrm{I} \quad=$ Not Confident (N) 2 = Somewhat Confident (S) 3 = Very Confident (V)

Rank your level of confidence to plan and teach a problem/decision-based activity during your student teaching experience.

$\begin{array}{lll}N & S & V \\ l & 2 & 3\end{array}$

Briefly explain your ranking.

How many problem/issue-based activities did you implement during your student teaching experience? (Circle below)

$\begin{array}{lllllll}0 & 1 & 2 & 3 & 4 & 5 & \text { more }\end{array}$

Please list/briefly describe the activity(ies) you implemented.

What were the most positive aspects/outcomes of the problem/decision-based activity(ies) you implemented?

What were the biggest challenges you encountered as you implemented your problem/decision-based activity(ies)?

Identify and explain factors that encouraged you to use problem/decision-based activities during your student teaching experience.

Identify and explain factors that discouraged or limited your use of problem/decision-based activities during your student teaching experience.

Do you plan to use problem-decision/based activities as you continue your career as a history/ social studies teacher? If so, why? If not, why not? 


\section{Appendix D}

Focus Group Moderator Instructions

Read the following.

The purpose of this focus group is to allow you to expand on your questionnaire responses. I will read each question and ask you to respond. The group will have five minutes to respond to each question. I will do my best to prompt responses from each of you and facilitate group discussion as we work our way through the questions.

Your responses will be audio recorded per the audio recording consent form you signed in August.

**(Make sure the recorder is on and working. Names should not be used.)

\section{Questions}

This questionnaire is designed to collect information about how you perceive your level of preparation and level of confidence in using problem/decision-based activities at this point in your year-long experience and the extent to which you have utilized problem/decision-based activities so far and why or why not.

Rank your level of preparedness to plan and teach a problem/decision-based activity during your student teaching experience.

$$
\text { I = Not Prepared (N) } 2 \text { = Somewhat Prepared (S) } 3 \text { = Very Prepared (V) }
$$

Briefly explain your ranking.

Rank your level of confidence to plan and teach a problem/decision-based activity during your student teaching experience.

$\mathrm{I}=$ Not Confident (N) 2 = Somewhat Confident (S) 3 = Very Confident (V)

Briefly explain your ranking.

How many problem/issue-based activities did you implement during your student teaching experience?

Please briefly describe the activity(ies) you implemented.

What were the most positive aspects/outcomes of the problem/decision-based activity(ies) you implemented?

What were the biggest challenges you encountered as you implemented your problem/decision-based activity(ies)?

Identify and explain factors that encouraged you to use problem/decision-based activities during your student teaching experience.

Identify and explain factors that discouraged or limited your use of problem/decision-based activities during your student teaching experience.

Do you plan to use problem-decision/based activities as you continue your career as a history/social studies teacher? If so, why? If not, why not? 


\section{Appendix E}

\begin{tabular}{|c|c|c|c|}
\hline $\begin{array}{l}\text { Participant } \\
\text { (Pseudonym) }\end{array}$ & $\begin{array}{l}\text { Demographics } \\
\text { (Gender, Age, Race/Ethnicity) }\end{array}$ & $\begin{array}{l}\text { Fall 20I5 Practicum Placement } \\
\text { (Middle School-MS or High School- } \\
\text { HS and Subjects Taught) }\end{array}$ & $\begin{array}{llr}\text { Subjects } & \text { Taught } & \text { During } \\
\text { Spring } 2016 & \text { Student } \\
\text { Teaching }(\mathrm{HS}) & \\
\end{array}$ \\
\hline Anne & Female, 23, White, & MS, 6th World Area Studies & I0th World History \\
\hline Bob & Male, 23, White & MS, 8th State Studies & $\begin{array}{l}10^{\text {th- }} 12^{\text {th }} \text { Sociology, } 10^{\text {th }} \\
\text { World History }\end{array}$ \\
\hline Carly & Female, 23, White & $\begin{array}{l}\text { MS, AC (Advanced) } 7^{\text {th }} \text { World Area } \\
\text { Studies, } 8^{\text {th }} \text { State Studies, 6th World } \\
\text { Area Studies }\end{array}$ & I Ith U.S. History \\
\hline Debra & Female, 25, African American & MS, 8th State Studies & $\begin{array}{l}\text { IIth US History and } 12^{\text {th }} \\
\text { Economics/ } \\
\text { Government }\end{array}$ \\
\hline Ed & Male, 25, White & MS, 8th State Studies & I Ith US History \\
\hline Frank & Male, 22, White & MS, 8th State Studies & $\begin{array}{l}\text { 10th Honors and On Level } \\
\text { World History, 10th-12th } \\
\text { Psychology }\end{array}$ \\
\hline Gary & Male, 23, White & $\begin{array}{l}\text { MS, } 6^{\text {th }} \text { and } 7^{\text {th }} \text { World } \\
\text { Area Studies }\end{array}$ & 9th American Government \\
\hline Hank & Male, 23, White & MS, 7 th World Area Studies & 10th World History \\
\hline lan & Male, 24, White & $\begin{array}{l}\text { MS, 7th World Area Studies, AC } \\
\text { (Advanced) \& On Level }\end{array}$ & I Ith US History \\
\hline Jane & Female, 24, Hispanic & $\begin{array}{l}\text { HS, 9th World Geography and 10th } \\
\text { World History }\end{array}$ & $\begin{array}{l}9^{\text {th }} \text { World Geography and } \\
\text { 10th World History }\end{array}$ \\
\hline Kathy & Female, 22, White & HS, I0th World History & 10th World History \\
\hline Lou & Male, 27, White & HS, I0th World History & 10th World History \\
\hline
\end{tabular}

Table 2: Fall 20 I5 History/Social Studies Methods Course Topical Outline
\begin{tabular}{|l|l|} 
Date & Topic \\
\hline $8 / 17$ & $\begin{array}{l}\text { Introduction to Course and Research Study, Methods and edTPA; Immersion: Lesson I-PBL- } \\
\text { Decade of Unrest; Orientation Meetings (in field) }\end{array}$ \\
\hline $8 / 24$ & Methods/edTPA Immersion continued (Lesson 2-PBL-Patriots v Loyalists) \\
\hline $8 / 31$ & $\begin{array}{l}\text { Purpose and Rationale of Social Studies Education; Nature and Needs of the Adolescent Learner } \\
\text { \& The Cognitive Dynamics of Teaching and Learning History/Social Studies }\end{array}$ \\
\hline $9 / 7$ & LABOR DAY \\
\hline $9 / 14$ & Methods Continuum; Concept Development; Lesson Plan Commentary Think-Aloud \\
\hline $9 / 21$ & Problem-Based Education; Classroom Management Orientation \\
\hline $9 / 28$ & Teach Live (Meet in Education Building Rm. I 28) \\
\hline I0/5 & Decision-Making; Teaching Controversial Issues \\
\hline I0/12 & Teaching with Primary Sources; Cooperative Learning; Lecture, Discussion, Questioning \\
\hline I0/19 & Assessing the Social Studies Learner; edTPA Planning Session \\
\hline $10 / 26$ & edTPA Task I Workshop and Peer Review \\
\hline II/2 & Knowing the Adolescent Learner; Tailoring Instruction; Differentiation \\
\hline II/9 & Connecting Theory to Practice \\
\hline II/16 & edTPA Task 2 and 3 Workshop and Peer Review \\
\hline II/23 & FALL BREAK \\
\hline II/30 & Show and Tell; Artifact Day; Sendoff \\
\hline $12 / 7$ & Final Conferences \\
\hline Note The \\
\hline
\end{tabular}

Note. The topical outline was copied from the course syllabus. 